\title{
In Vitro Differences of Neonatal and Later Postnatal Keratinocytes and Dermal Fibroblasts
}

\author{
E. KREJČÍ ${ }^{1}$, O. KODET ${ }^{1,2}$, P. SZABO ${ }^{1}$, J. BORSKÝ ${ }^{3}$, K. SMETANA Jr. ${ }^{1}$, M. GRIM ${ }^{1}$, \\ B. DVOŘÁNKOVÁ ${ }^{1}$
}

${ }^{1}$ Institute of Anatomy, First Faculty of Medicine, Charles University, Prague, Czech Republic, ${ }^{2}$ Department of Dermatology and Venereology, First Faculty of Medicine, Charles University, Prague, Czech Republic, ${ }^{3}$ Department of ENT, Second Faculty of Medicine, Charles University in Prague and Motol University Hospital, Prague, Czech Republic

Received August 15, 2014

Accepted October 24, 2014

On-line December 3, 2014

\section{Summary}

Skin healing process is postnatally always associated with scarring of various extent. Based on the clinical experience of plastic surgeons, the healing after lip cleft reconstruction is surprisingly almost scar-less when it is carried out within a few first days after birth. This phenomenon is not seen in delayed cases. In order to decipher causative mechanism, we have isolated and studied principal cell populations, keratinocytes and fibroblast, from residual tissue samples after reconstructive operation $(\mathrm{N}=39)$ performed at various age (0-9 years). These cells play the pivotal role in the healing and that is why we focused on description of their phenotype and also functionality with respect to age. We have identified a population of remarkably small cells in explants from newborns (day 0-10). These small cells were strongly positive for markers of low differentiated keratinocytes, keratin-8 and -19 , and moreover also for vimentin. In the explants cultures from older babies this population was missing. Fibroblasts from newborns and older patients differed namely in terms of nestin expression and also in the production of extracellular matrix components. We conclude that in vitro described properties of keratinocytes and fibroblasts in newborns could participate on the almost scar-less wound healing in earliest neonatal period.

\section{Key words}

Newborn skin - Neonatal surgery - Scar-less healing • Keratinocyte $\bullet$ Fibroblast

\section{Corresponding author}

B. Dvoránková, Institute of Anatomy, First Faculty of Medicine, Charles University in Prague, U nemocnice 3, 12800 Prague 2, Czech Republic. E-mail: bdvorankova@seznam.cz

\section{Introduction}

Scarring represents a common aspect of skin wound healing and is present in variable extents in postnatal mammals including humans. However, the results of early performed neonatal surgery of the lip cleft demonstrated repeatedly almost scar-less healing (Borský et al. 2012) (Fig. 1). This phenomenon was also observed in the prenatal healing. These data match with observation of very high regenerative potential of the tip of digit seen in newborn mouse (Han et al. 2008). Such observations indicate certain overlap of features of tissue in fetal and early neonatal period when the high level of regenerative capacity is resulting in the reduction of scar formation (Smetana et al. 2013). Significant differences between fetal and adult skin were observed also in humans. These include predominantly age-dependent differences in terminal differentiation of keratinocytes reflected by expression of keratins in epidermis and significantly lower presence of chondroitin sulfate and fibronectin in the adult dermis (Coolen et al. 2010). Moreover, there are significant differences in immune response between fetuses and adults (Bukovsky et al. 2009). This is reflected by significant differences in 
production of mediators such as IL-6, IL- 8 and TGF- $\beta$ (Eslami et al. 2009, Bermudez et al. 2011). The role of the latter one in fibrosis and scar formation is well known. These data indicate significant differences in the intercellular interactions in the course of wound healing. Predominantly, the inflammatory response is also significantly influenced by the age of patient. Unfortunately, the differences of keratinocytes and dermal fibroblasts in the course of early childhood are not well described yet. In this study we present the basic in vitro properties of keratinocytes and fibroblasts prepared from explants of oral mucosa and skin of the lips from newborns. For purposes of this study, newborn period is defined as beginning at birth lasting through the $10^{\text {th }}$ day following birth only. Cells prepared from the similar residual tissues obtained from the infants and children of higher age ( 3 months to 9 years) are used as controls. Our research is focused predominantly on expression of distinct types of keratins, vimentin, nestin and some nuclear markers of embryonic stem cells. The size of keratinocytes and production of extracellular matrix by fibroblasts is also evaluated.
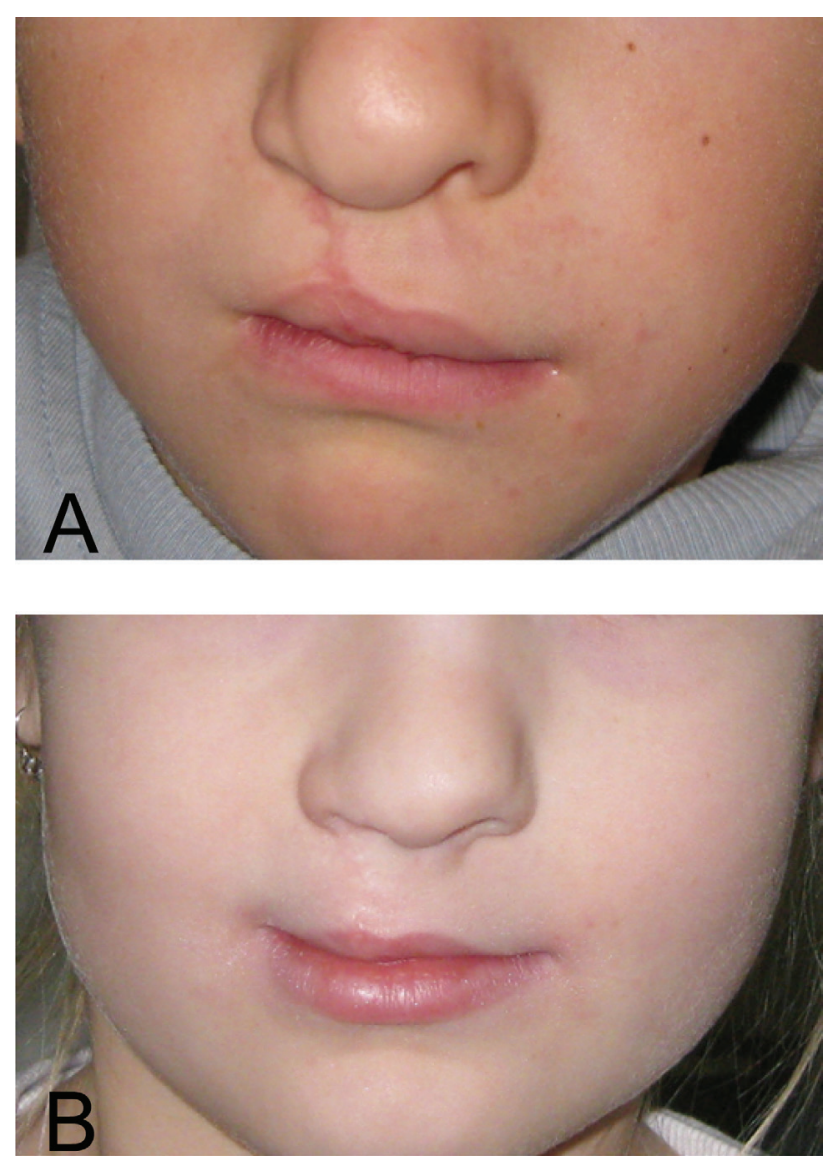

Fig. 1. Comparison of results of lip cleft reconstructive surgery performed in later childhood ( 3 months $-\mathbf{A}$ ) and in neonatal period (B) 6 years after the surgery.

\section{Material and Methods}

\section{Isolation of the cells}

The residual pieces of the of tissue were obtained from the lip and palate cleft reconstructions performed at the Department of Pediatric Surgery, $2^{\text {nd }}$ Faculty of Medicine, Charles University in Prague and at the Department of Plastic Surgery, $3^{\text {rd }}$ Faculty of Medicine, Charles University in Prague, respectively. All samples were obtained after approval of the local ethical committee with written informed consent of patient's legal representatives. The cohort of donors is characterized in Table 1. Skin and mucosa were separated by dissection under stereomicroscope and cut to very small pieces (up to $1 \mathrm{~mm}^{3}$ ) which were shortly digested in $0.25 \%$ trypsin (Sigma Aldrich, Prague, Czech Republic) for $20 \mathrm{~min}$ at $37^{\circ} \mathrm{C}$. Digested explants were transferred into CellBind six-well plates (Corning, Schiphold Rijk, the Netherland) in minimal volume of Dulbecco's Modified Eagle Medium (DMEM, Biochrom, Berlin, Germany) supplemented with $10 \%$ of Fetal Bovine Serum (FBS, Biochrom, Berlin, Germany) and $100 \mu \mathrm{g} / \mathrm{ml}$ Gentamycin (Sigma Aldrich, Prague, Czech Republic) and kept for $24 \mathrm{~h}$ at $37^{\circ} \mathrm{C}$ and $5 \% \mathrm{CO}_{2}$ in humidified incubator. On the next day volume of culture media was increased. Emerging fibroblasts and keratinocytes were evident after a few days. These two populations were separated by differential trypsinization, $1: 1 \mathrm{v} / \mathrm{v}$ mixtures of $0.25 \%$ trypsin and $0.02 \%$ ethylenediaminetetraacetic acid (EDTA, Biochrom, Berlin, Germany) to harvest fibroblasts and 1:3 v/v mixture for keratinocytes. The cells from earliest passages were characterized immunocytochemically according to their phenotype. For purposes of this study culture where more than $90 \%$ of cells were negative for leukocyte marker CD45, melanocyte markers (MELANA, HMB-45) and keratins and positive for vimentin was considered fibroblasts. Cells where more than $90 \%$ of them were negative for leukocyte and melanocyte markers and positive for keratins were considered keratinocytes.

Table 1. Characteristic of proband cohort.

\begin{tabular}{lcc}
\hline Proband & Male & Female \\
\hline 1-10 days & 19 & 10 \\
3 months-9 years & 6 & 4 \\
\hline
\end{tabular}




\section{Culture of fibroblasts}

Both skin and mucosa fibroblasts (third passage) were inoculated on the cover slips in the density 3000 cells $/ \mathrm{cm}^{2}$ and subsequently cultured four days in DMEM with $10 \%$ FBS. In indicated experiments, skin fibroblasts were cultured in medium suitable for neural crest cells consisting of alpha-MEM (Gibco, Grand Island, NY, USA), $10 \%$ FBS, $100 \mathrm{mg} / \mathrm{ml}$ Gentamycin and $5 \%$ extract from 11-day old chick embryos as described in details in Krejčí and Grim (2010).

\section{Culture of keratinocytes}

Keratinocytes from the second subculture were cultured on Mitomycin C treated mouse embryonic 3T3 cells feeder. Feeder was prepared from the subconfluent monolayer of 3T3 cells (ATCC CCL-92, Manassas, USA) treated for $3 \mathrm{~h}$ with $16 \mu \mathrm{g} / \mathrm{ml}$ solution of Mitomycin C (Sigma Aldrich, Prague, Czech Republic) in DMEM with $10 \%$ FBS. Feeder was seeded at density 30000 cells $/ \mathrm{cm}^{2} 24 \mathrm{~h}$ before keratinocytes were added to the culture system at identical density. Keratinocytes were cultivated for six days in keratinocyte medium DMEM+F12 3:1 with 10\% FBS, supplemented with $0.4 \mu \mathrm{g} / \mathrm{ml}$ Hydrocortisone, $10^{-10} \mathrm{M}$ Cholera Toxin, $10 \mathrm{ng} / \mathrm{ml}$ Epidermal Growth Factor (all Sigma Aldrich,
Prague, Czech Republic) and $0.12 \mathrm{U} / \mathrm{ml}$ insulin Actrapid (Novo Nordisk, Bagsvaerd, Denmark).

\section{Immunocytochemistry}

The cover slips with cultured cells were fixed by $2 \%(\mathrm{w} / \mathrm{v})$ paraformaldehyde in phosphate-buffered saline (PBS) for $10 \mathrm{~min}$, washed with PBS and permeabilized with Triton X-100 (Sigma-Aldrich, Prague, Czech Republic). The non-specific binding of immunoglobulins via Fc receptors was blocked by $3.3 \%$ non-immune porcine serum (DAKO, Glostrup, Denmark). The panel of used markers is summarized in Table 2, appropriate antibody dilution was performed as recommended by the supplier. The specificity of binding of the secondary antibodies was tested by isotype controls. Cell nuclei were counterstained with 4',6-diamidino-2-phenylindole (DAPI; Sigma-Aldrich, Prague, Czech Republic). The stained coverslips were mounted to Vectashield (Vector Laboratories, Peterborough, UK) and analyzed by Eclipse 90i fluorescence microscope (Nikon, Prague, Czech Republic) equipped with Cool-1300Q CCD camera (Vosskühler, Osnabrück, Germany) and LUCIA 5.1 computer-assisted image analysis system (Laboratory Imaging, Prague, Czech Republic). Using this system 500 cells were always analyzed to obtain quantitative

Table 2. Antibodies used for immunocytochemical analysis.

\begin{tabular}{|c|c|c|c|}
\hline Primary antibody & Producer & $\begin{array}{l}\text { Secondary antibody/ } \\
\text { Fluorochrome }\end{array}$ & Producer \\
\hline $\begin{array}{l}\text { Wide spectrum } \\
\text { cytokeratin } / P\end{array}$ & Abcam, Cambridge, UK & \multirow[t]{2}{*}{$\begin{array}{l}\text { Swine anti-rabbit, } \\
\text { fluorochrome/FITC }\end{array}$} & \multirow[t]{2}{*}{$\begin{array}{l}\text { DAKO, Glostrup, } \\
\text { Denmark }\end{array}$} \\
\hline $\begin{array}{l}\text { Cytokeratin } 8 / P \\
\text { Nestin } / P \\
\text { Oct- } 4 / P \\
\text { Fibronectin } / P\end{array}$ & $\begin{array}{l}\text { Sigma-Aldrich, Prague, } \\
\text { Czech Republic }\end{array}$ & & \\
\hline $\begin{array}{l}\text { High molecular weight } \\
\text { cytokeratin/M } \\
\text { Cytokeratin 19/M } \\
\text { Vimentin/M }\end{array}$ & Dako, Glostrup, Denmark & \multirow[t]{2}{*}{ Goat anti-mouse/TRITC } & \multirow[t]{2}{*}{ Sigma-Aldrich } \\
\hline $\begin{array}{l}\text { Cytokeratin 14/M } \\
\text { Tenascin } / M\end{array}$ & Sigma-Aldrich & & \\
\hline Nanog/M & $\begin{array}{l}\text { R\&D System, } \\
\text { Minneapolis, USA }\end{array}$ & $\begin{array}{l}\text { Donkey anti-goat, } \\
\text { Fluorochrome/TRITC }\end{array}$ & $\begin{array}{l}\text { Santa Cruz } \\
\text { Biotechnology, Dallas, } \\
\text { USA }\end{array}$ \\
\hline
\end{tabular}

$\mathrm{P}=$ rabbit polyclonal antibody, $\mathrm{M}=$ mouse monoclonal antibody 
data for cell size and phenotypic characterization. These data were evaluated by unpaired Student's t-test.

\section{Results}

Differences between keratinocytes from newborns and older infants

We have identified a subpopulation of remarkably small cells (diameter $4 \mu \mathrm{m}$ in average) in keratinocyte cultures from explants from both skin and mucosa respectively. These cells formed small loose colonies and exhibited obvious lack of tendency to form intercellular contacts. These small cells were specific only for cultures from newborns and we were not able to observe them in explant cultures from older donors (Fig. 2). Almost all neonatal small keratinocytes (positive for keratins), surprisingly, also co-expressed vimentin (Fig. 2 A,I). Marker of basal keratinocytes, keratin 14, was detected in all of these cells (Fig. 2 D,L). Keratin 8 and 19, markers of low level of keratinocyte differentiation, were present in high proportion in keratinocytes from newborns (Fig. 2 B,C), this proportion was higher in cells prepared from neonatal mucosa than from skin (Fig. $2 \mathrm{~J}, \mathrm{~K}$ ). Keratinocytes isolated from the older donors exhibited lower percentage of cells positive for studied markers with two exceptions. There was no age related difference in positivity for keratin 8 in skin keratinocytes and also for keratin 14 in mucosal keratinocytes (Fig. 2 B,F,L,P). The precise level of coexpression of keratin and vimentin and keratin 8 and 19 at the single cell level was also verified by the measurements of fluorescence intensity profile (Fig. 3 A,C). When the function of gradient morphology in image analyzer was used, vimentin was predominantly present in polarized part of cells (Fig. 3 B).

Small keratinocytes from skin of newborns expressed in vitro also markers of embryonic stem cells Oct-4 and Nanog; this was not seen in corresponding mucosal keratinocytes. Interestingly, the feeder cells exhibited both studied markers in higher extent than keratinocytes; this can be employed as the internal positive control of immunocytochemical reaction. These results were also verified by the fluorescence intensity measurements (Fig. 3 D,E).

\section{Difference between fibroblasts from newborns and older} infants

All fibroblasts regardless the origin or age of donors shared typical elongated fusiform morphology and high expression of vimentin (Fig. 4). We focused our attention first on nestin, marker reflecting the differentiation status. Expression of this protein was strongly age dependent in cells isolated either from skin or mucosa. Almost all fibroblasts were positive for nestin in newborns (Fig. 4 A,B). At the age of 9 months only $50 \%$ of fibroblasts still remained positive for nestin (Fig. 4 C,D). The further decrease in nestin positivity was rather dramatic, only sporadic positivity for nestin was observed in fibroblasts from donors aged 5 years and more (Fig. 4 E,F). Unlike the corresponding keratinocytes, neither cutaneous nor mucosal fibroblasts expressed Oct4 and Nanog regardless the age of the donor (Fig. 4 G,H). Only in one case (out of 29 newborns) we found clear positivity of Oct-4 and Nanog in cutaneous fibroblasts and of Oct-4 in mucosal fibroblasts (data not shown). Interestingly, absence of these markers in fibroblasts is not cell type specific, but reflects sensitively cell culture microenvironmental conditions as depicted by culture of fibroblasts from newborns under conditions suitable for neural crest stem cells. In this medium fibroblasts express both markers of pluripotency i.e. Oct-4 and Nanog (Fig. 4 I,J).

The main functional aspect of fibroblasts is the production of extracellular matrix components (ECM). Among many others, fibronectin and tenascin represent the principal constituents of ECM important namely during course of wound healing. Comparison of the production of these ECM molecules showed significantly lower production in neonatal fibroblasts compared to those isolated from 9-month-old baby and older ones (Fig. 4 K-L1).

\section{Discussion}

The main finding of this study is the observation that keratinocytes and fibroblasts isolated from skin and mucosa of newborns significantly differ in vitro from similar cells isolated from older infants and children. The most prominent feature of keratinocyte explants from newborns was a unique subpopulation of remarkably small keratinocytes $(4 \mu \mathrm{m}$ in diameter) forming loose colonies. Certain parallel of this might be found in small cells highly resistant to anoikis presenting also some features of epidermal stemness which were observed in small proportion even in the cell suspension prepared from the adult human epidermis as reported by us earlier elsewhere (Dvořánková et al. 2005). On the contrary, outgrowth of these small cells from adult tissue source 
Epidermal keratinocytes: newborn, $d=3.97 \pm 0.9 \mu \mathrm{m} \star$

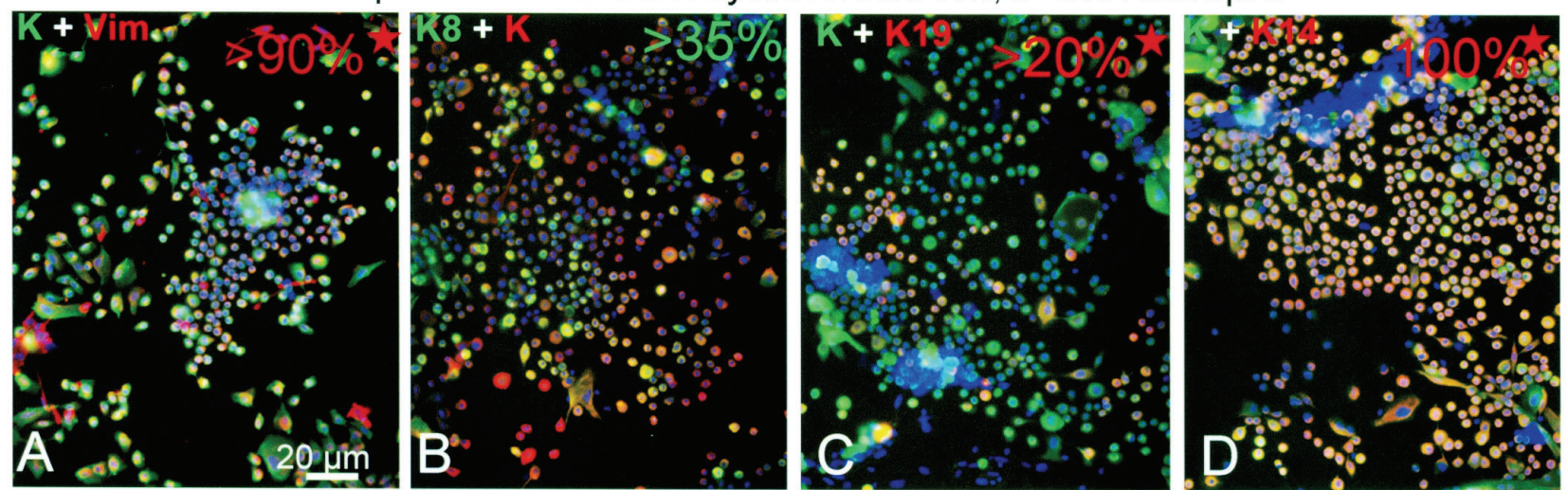

Epidermal keratinocytes: 9 months, $d=9.87 \pm 4.32 \mu \mathrm{m}$
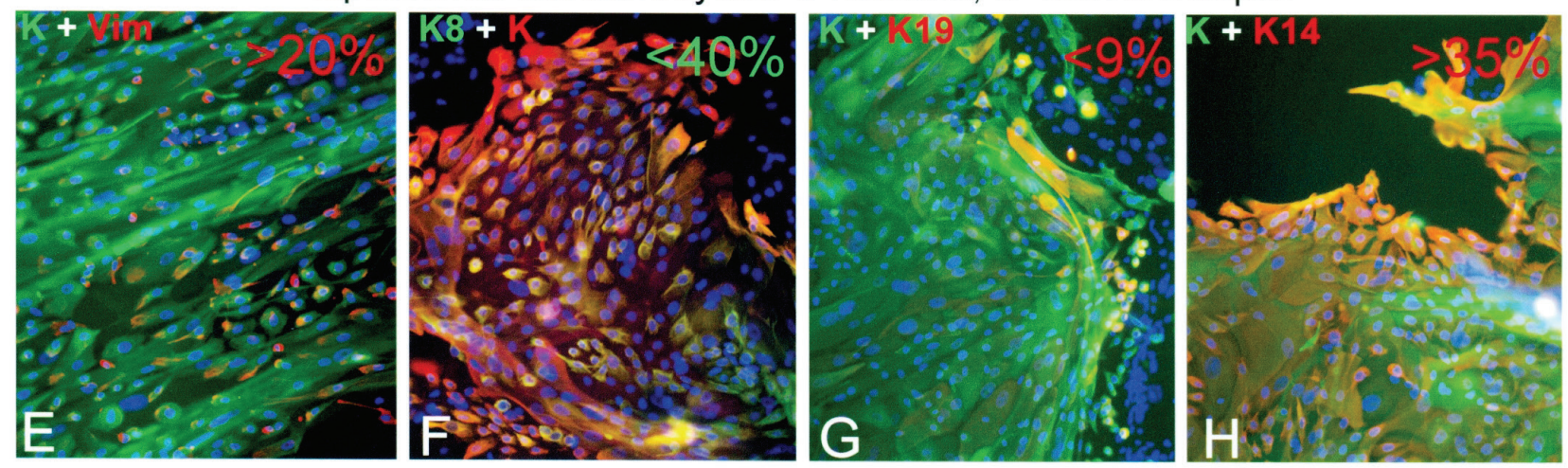

Mucosal keratinocytes: newborn, $\mathrm{d}=4.05 \pm 1.05 \mu \mathrm{m} \star$

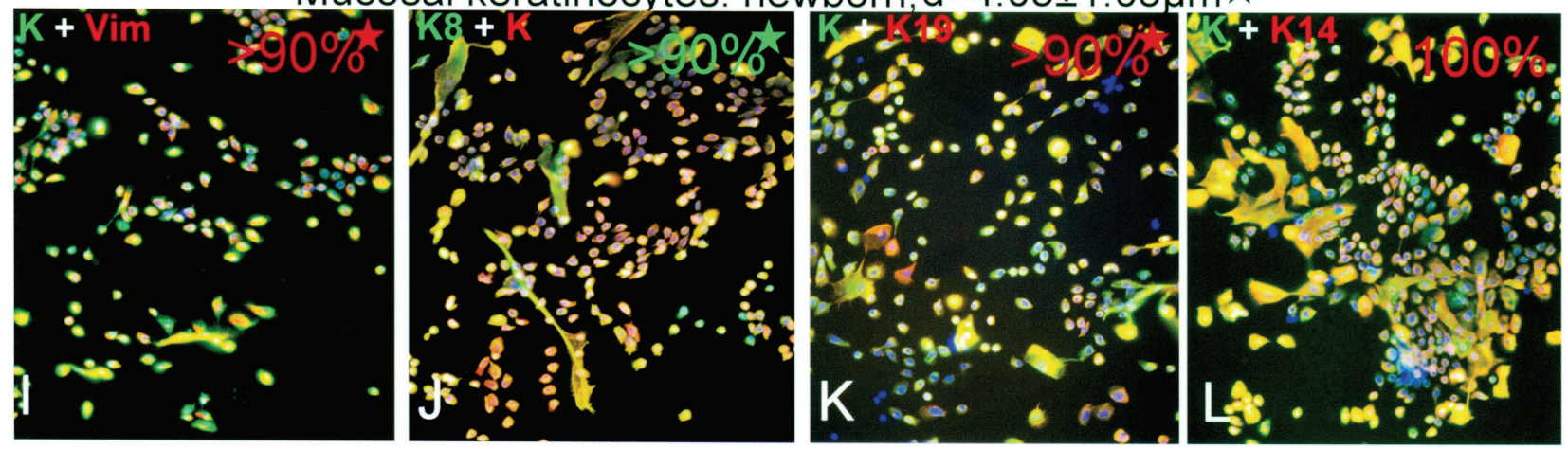

Mucosal keratinocytes: 14 months, $d=7.68 \pm 3.06 \mu \mathrm{m}$
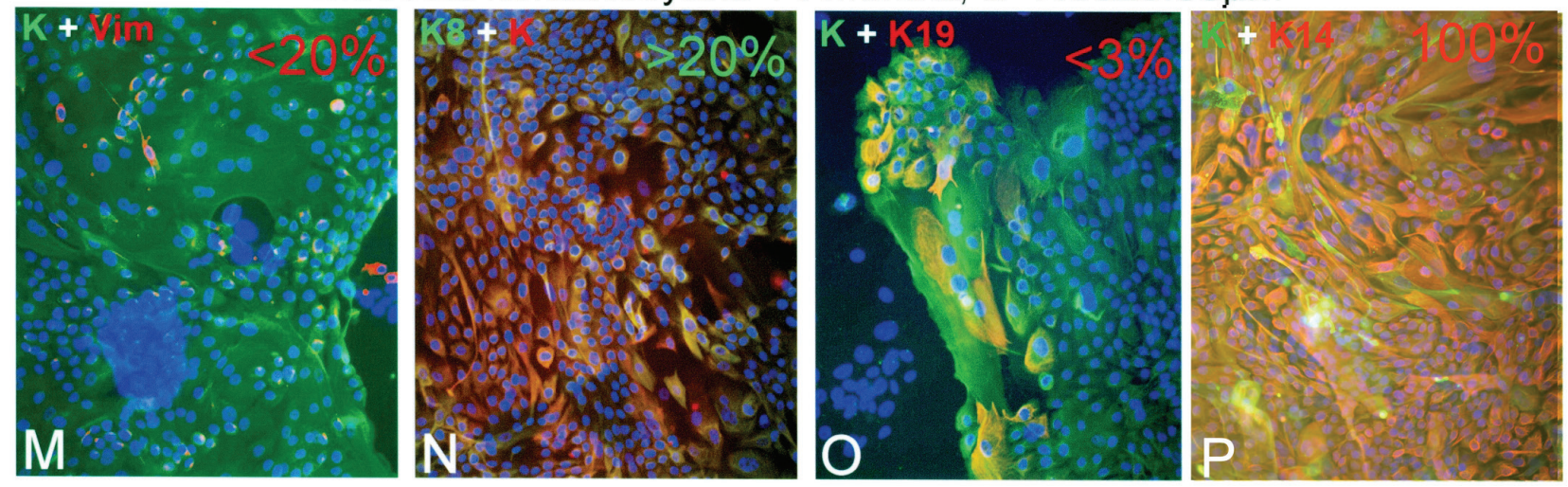

Fig. 2. Immunocytochemical phenotypization of cultured keratinocytes. Keratinocytes are cells positive for keratins (K) and moreover there was detected keratin 8 (K8), keratin 14 (K14), keratin 19 (K19) and Vimentin (Vim). The percentage of the cells positive for each marker is indicated on every picture. $\mathrm{K} / \mathrm{S}$ - keratinocytes isolated from the skin; $\mathrm{K} / \mathrm{M}$ - keratinocytes isolated from the mucosa. For each age group the average diameter of the cells was determined. Significant difference between neonatal and older babies' cells at $p<0.05$ is marked by asterisk (unpaired Student's t-test). 

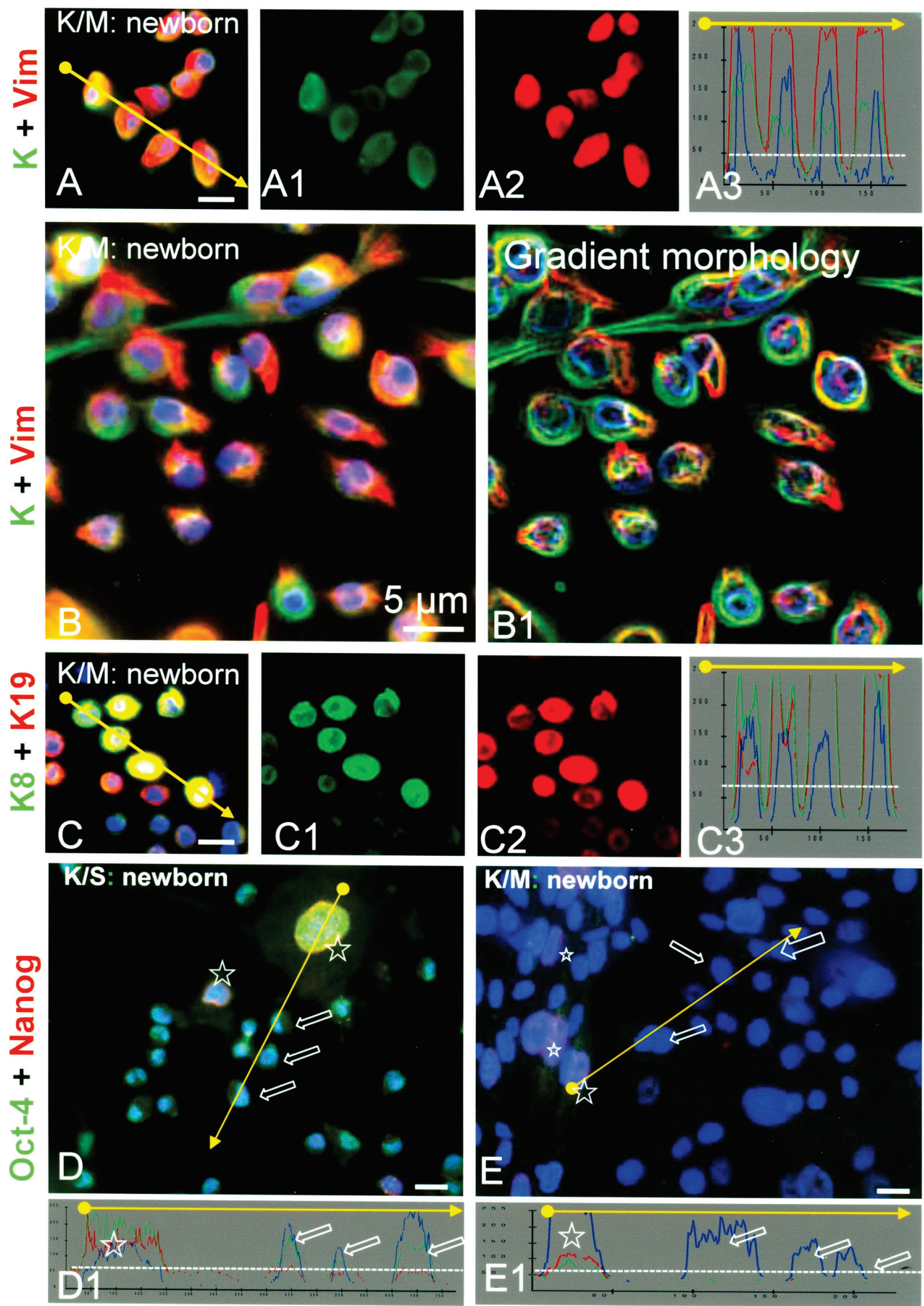

Fig. 3. Co-localization of keratins (A, A1) and vimentin (A2) in newborn mucosa keratinocytes is validated using complete picture, signals in single channels (green and red) and fluorescence intensity profile of four labeled cells (A3). Expression of vimentin in newborn mucosa keratinocytes is localized namely on the migration front of the cells what was verified by gradient morphology (B). Colocalization of keratin 8 and keratin 19 (C, C1, C2) in newborn mucosa keratinocytes is validated using complete picture, signals in single channels (green and red) and fluorescence intensity profile of three labeled cells (C3). Detection of Oct-4 and Nanog in skin (D) and mucosa (E) newborn keratinocytes. The cells labeled with asterisk are 3T3 feeder cells, those labeled with arrow are keratinocytes. The expression of detected markers is also shown on fluorescence intensity profile (D1, E1), where white dashed line represents the background intensity. Keratinocytes are marked by the same abbreviations as in Fig. 2. 

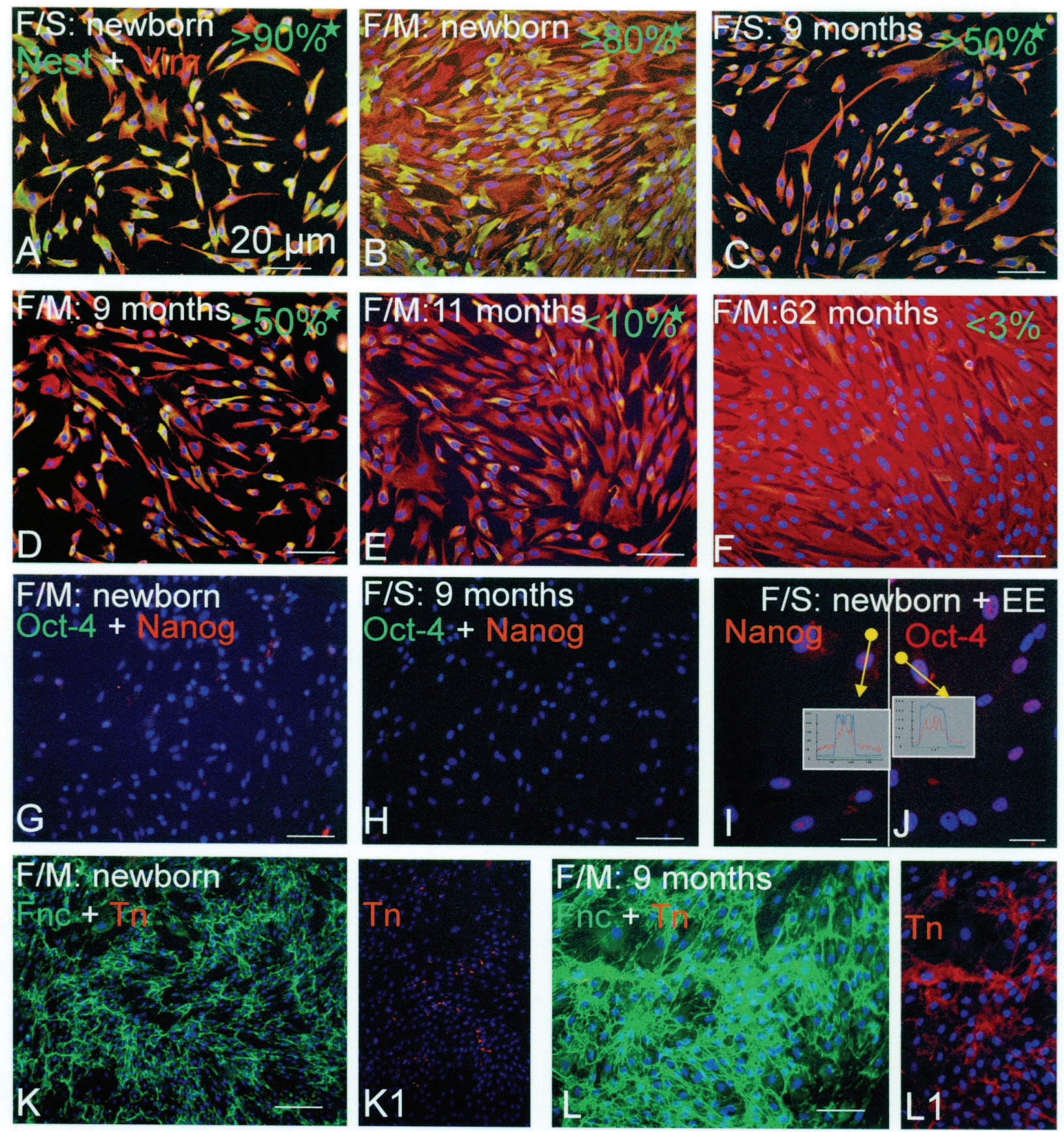

Fig. 4. Detection of nestin (Nest) expression in fibroblasts, which were characterized by vimentin (Vim) positive cytoskeleton (A-F). The percentage of the cells positive for nestin is indicated on each picture. Significant difference between 62 months old fibroblast and the younger ones at $p<0.05$ is marked by asterisk (Student's unpaired t-test). Detection of Oct- 4 and Nanog in mucosa fibroblasts isolated from newborn (G) and older baby (H) as well as in neonatal skin fibroblasts cultured in presence of chick embryonic extract (EE), where the positivity for both signals was ascertained $(\mathbf{I}, \mathbf{J})$ as was also verified using detection of fluorescence intensity measurements. Production of extracellular matrix rich for fibronectin $(\mathbf{K}, \mathbf{L})$ and tenascin $(\mathbf{K}, \mathbf{K 1}, \mathbf{L}, \mathbf{L 1})$ was lower in case of neonatal fibroblasts $(\mathbf{K}$, K1) than in fibroblasts from older babies (L, L1). Fibroblasts of different origin (F/S - fibroblasts isolated from the skin; F/M fibroblasts isolated from the mucosa) and from different age groups were compared.

was not reported. These very small cells are of comparable size as cells with strong multipotent potential which were observed in a very low proportion in the bone marrow and which might be released to circulation after e.g. skin burn injury (Drukala et al. 2012). The small size and expression of pluripotency-associated markers in epidermal cells in newborns can be a promise for further studies related to microenvironment and stemness maintenance. Detection of a very high proportion of neonatal skin/mucosal small cells with expression of vimentin did another point of this study. We observed frequently presence of vimentin in keratinocytes in vitro 
stimulated by presence of cancer associated fibroblasts (Lacina et al. 2007, Strnad et al. 2010). This phenomenon was interpreted in context of cancer studies as illustration of emerging epithelial-mesenchymal transition. However, this process is undisputedly important for the wound healing as well. The polarization of vimentin expression in keratin-positive small cells observed in this study is in agreement with this idea. In small neonatal keratinocytes the expression of keratin 8 and 19 (Strnad et al. 2010) also harmonizes with this hypothesis.

Reduced expression of nestin in fibroblasts was observed during the aging of donors. Although nestin is not reliable marker of stemness, it somewhat reflects the differentiation level and cell potential to proliferate (Michalczyk and Ziman 2005). Therefore the reduction of this protein with increasing age of cell donor is not so surprising and it was also observed by others (Béguin et al. 2012). Fibroblasts of head and neck region originate from the so called ectomesenchyme of neural crest (Gitton et al. 2011). The positivity for Oct-4 and Nanog found in neonatal fibroblasts cultured under the condition supporting stemness in this lineage (Krejčí and Grim 2010) is therefore not surprising.

The production of both fibronectin and tenascin by fibroblasts isolated from newborns seems to be lower compared to control fibroblasts of older donors. This result confirms antifibrotic activity of neonatal fibroblasts reported by others (Pratsinis et al. 2013). These finding can also illustrate the reduced scar formation observed by us in newborns undergoing surgery during the first 10 days of life. We can hypothesize that process of scar formation is influenced by the dysbalance between extracellular matrix formation and its resorption in the process of the wound site remodeling.

In conclusion, keratinocytes and fibroblasts from newborns significantly differ from the cells prepared from older infants and children. These differences can be responsible for reduced scarring after surgical interventions performed during early days after the birth.

\section{Conflict of Interest}

There is no conflict of interest.

\section{Acknowledgements}

The study was supported by the Grant Agency of the Czech Republic, project No. 13-20293S, by the Charles University projects PRVOUK-27 and UNCE 204013 as well as by the EC projects BIOCEV (Biotechnology and Biomedicine Centre of the Academy of Sciences and Charles University in Vestec - CZ.1.05/1.1.00/02.0109 from the European Regional Development Fund). Authors are grateful to Marie Jindráková, Radana Kavková and Alena Kvasilová for excellent technical assistance.

\section{References}

BÉGUIN PC, GOSSELIN H, MAMARBACHI M, CALDERONE A: Nestin expression is lost in ventricular fibroblasts during postnatal development of the rat heart and re-expressed in scar myofibroblasts. J Cell Physiol 227: 813820, 2012.

BERMUDEZ DM, CANNING DA, LIECHTY KW: Age and pro-inflammatory cytokine production: wound-healing implications for scar-formation and the timing of genital surgery in boys. J Pediatr Urol 7: 324-331, 2011.

BORSKY J, VELEMINSKA J, JUROVCIK M, KOZAK J, HECHTOVA D, TVRDEK M, CERNY M, KABELKA Z, FAJSTAVR J, JANOTA J, ZACH J, PETERKOVA R, PETERKA M: Successful early neonatal repair of cleft lip within first 8 days of life. Int J Pediatr Otorhinolaryngol 76: 1616-1626, 2012.

BUKOVSKY A, CAUDLE MR, CARSON RJ, GAYTAN F, HULEIHEL M, KRUSE A, SCHATTEN H, TELLERIA $\mathrm{CM}$ : Immune physiology in tissue regeneration and aging, tumor growth, and regenerative medicine. Aging $\mathbf{1}$ : 157-181, 2009.

COOLEN NA, SCHOUTEN KC, MIDDELKOOP E, ULRICH MM: Comparison between human fetal and adult skin. Arch Dermatol Res 302: 47-55, 2010.

DRUKALA J, PACZKOWSKA E, KUCIA M, MLYNSKA E, KRAJEWSKI A, MACHALINSKI B, MADEJA Z, RATAJCZAK MZ: Stem cells, including a population of very small embryonic-like stem cells, are mobilized into peripheral blood in patients after skin burn injury. Stem Cell Rev 8: 184-194, 2012.

DVOŘÁNKOVÁ B, SMETANA K Jr, CHOVANEC M, LACINA L, ŠTORK J, PLZÁKOVÁ Z, GALOVIČOVÁ M, GABIUS H-J: Transient expression of keratin 19 is induced in originally negative interfollicular epidermal cells by adhesion of suspended cells. Int J Mol Med 16: 525-531, 2005. 
ESLAMI A, GALLANT-BEHM CL, HART DA, WIEBE C, HONARDOUST D, GARDNER H, HÄKKINEN L, LARJAVA HS: Expression of integrin $\alpha \mathrm{v} \beta 6$ and TGF- $\beta$ in scarless vs scar-forming wound healing. J Histochem Cytochem 57: 543-557, 2009.

GITTON Y, BENOUAICHE L, VINCENT C, HEUDE E, SOULIKA M, BOUHALI K, COULY G, LEVI G: Dlx5 and Dlx6 expression in the anterior neural fold is essential for patterning the dorsal nasal capsule. Development 138: 897-903, 2011.

HAN M, YANG X, LEE J, ALLAN CH, MUNEOKA K: Development and regeneration of the neonatal digit tip in mice. Dev Biol 315: 125-135, 2008.

KREJČÍ E, GRIM M: Isolation and characterization of neural crest stem cells from adult human hair follicles. Folia Biol (Praha) 56: 149-157, 2010.

LACINA L, DVOŘÁNKOVÁ B, SMETANA K Jr, CHOVANEC M, PLZÁK J, TACHEZY R, KIDERYOVÁ L, KUČEROVÁ L, ČADA Z, BOUČEK J, KODET R, ANDRÉ S, GABIUS H-J: Marker profilig of normal keratinocytes identifies the stroma from squamous cell carcinoma of the oral cavity as a modulatory microenvironment in co-culture. Int J Radiat Biol 83: 837-848, 2007.

MICHALCZYK K, ZIMAN M: Nestin structure and predicted function in cellular cytoskeletal organisation. Histol Histopathol 20: 665-671, 2005.

PRATSINIS H, ARMATAS A, DIMOZI A, LEFAKI M, VASSILIU P, KLETSAS D: Paracrine anti-fibrotic effects of neonatal cells and living cell constructs on young and senescent human dermal fibroblasts. Wound Repair Regen 21: 842-851, 2013.

SMETANA K Jr, DVOŘÁNKOVÁ B, LACINA L: Phylogeny, regeneration, ageing and cancer: role of microenvironment and possibility of its therapeutic manipulation. Folia Biol (Praha) 59: 207-216, 2013.

STRNAD H, LACINA L, KOLÁŘ M, ČADA Z, VLČEK Č, DVOŘÁNKOVÁ B, BETKA J, PLZÁK J, CHOVANEC M, ŠÁCHOVÁ J, VALACH J, URBANOVÁ M, SMETANA K Jr: Head and neck squamous cancer stromal fibroblasts produce growth factors influencing phenotype of normal human keratinocytes. Histochem Cell Biol 133: 201-211, 2010. 